\title{
Factors Affecting Airline Profits: Evidence From The Philippines
}

\author{
Wilfred S. Manuela Jr., Ateneo de Manila University, Philippines
}

\begin{abstract}
This article examines the factors that affect the profits of four airlines in the Philippines. The estimated profit equation indicates that an additional passenger contributes PHP 1,989 to profits, while an additional seat reduces profits by PHP 1,312. The findings indicate that airlines have a strong incentive to fill a seat before departure, justifying the practice of heavy discounting to stimulate passenger traffic during periods of low demand. An additional route reduces profits by PHP 107.736 million, which may indicate that new routes have lower-than-expected passenger traffic. This may also suggest that most profitable routes are already served by at least one airline and entry into existing routes may not be profitable. The 1997 Asian financial crisis, the 2001 terror attacks in the United States, and the most recent global financial crisis, collectively result in PHP 1.391 billion reduction in profits, underscoring the vulnerability of the airline industry to unanticipated events.
\end{abstract}

Keywords: Airline Profits; Philippine Airline Industry

\section{INTRODUCTION}

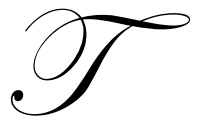

he Philippines liberalized its domestic airline industry in 1995 under Executive Order 219. Economic theory predicts that a more competitive environment tends to reduce industry profits, especially when the industry evolves from a single firm (monopoly) into a few firms with different degrees of market power (oligopoly), which is the case in the Philippines. Grand Air entered in 1995 while Air Philippines, Asian Spirit, and Cebu Pacific Air (CEB) entered the following year. Asian Spirit and Air Philippines changed their names to Zest Airways (Zest) in 2008 and Airphil Express (Airphil) in 2009, respectively.

Grand Air exited the industry in late 1998 while South East Asian Airlines (SEAir), a charter operator, entered the scheduled airline industry in 2003, bringing the number of active airlines to five. The country's so-called low-cost airlines like CEB and Airphil, which entered the scheduled airline industry in 1996, are exacerbating PAL's already dire financial situation. In 1999 PAL abandoned its service in low-density markets and focused on its most profitable routes to stay in competition. The competition between PAL and the other airlines resulted in substantial losses for the scheduled airline industry from 1995-2009 (see Table 1), underscoring the difficulty to generate profits in an industry noted for its vulnerability to economic fluctuations and erratic earnings (Thompson and Gamble, 2001). By 2009 PAL, CEB, Airphil, Zest, and SEAir compete for almost 14.7 million domestic passengers, up 198\% from its 1995 level, outpacing the growth in capacity or passenger seats, which increased $176 \%$ in the same period. The load factor then is higher in 2009 than in 1995, a positive development in an industry characterized by losses and bankruptcies. Airphil and Zest reported 10 and six years of losses, respectively, since entering the industry; PAL reported losses for eight years between 1995 and 2009 while CEB reported a loss only in 2008 (see Table 1), due to its hedging activities on fuel (PHP 2.5 billion) and foreign exchange (PHP 1.5 billion).

This article examines the factors that affect airline profits in the Philippines. Only four airlines-PAL, CEB, Airphil, and Zest - are included in the study because SEAir is relatively small and does not compete directly with the four airlines by focusing its operations on short-haul but profitable routes. Airphil, CEB, and PAL mostly compete on major and high-density routes while Zest has recently entered a number of routes dominated by PAL and CEB. Airphil, which has a code-share agreement with PAL and owned by PAL Holdings, operates a number of PAL's domestic flights. 
The paper is organized as follows. A brief literature review follows the introduction and then the discussion of the empirical framework and econometric model follows. The fourth section discusses the sample data and methodology while the fifth section presents the estimation results and analysis. The last section concludes the paper and discusses its limitations as well as directions for future work.

Table 1: Philippine Scheduled Airline Industry Profits (In Million PHP)

\begin{tabular}{|c|c|c|c|c|c|c|c|}
\hline Year & Industry & PAL & Grand Air & CEB & Airphil & Zest & SEAir \\
\hline 1995 & $-1,634.13$ & $-1,716.91$ & 82.78 & & & & \\
\hline 1996 & $-2,105.60$ & $-2,182.28$ & 234.50 & 27.19 & -185.40 & 0.39 & \\
\hline 1997 & $-2,035.71$ & $-2,502.00$ & 209.69 & 130.45 & 119.78 & 6.37 & \\
\hline 1998 & $-8,264.41$ & $-8,581.00$ & -21.50 & 301.71 & 40.01 & -3.63 & \\
\hline 1999 & $-10,648.39$ & $-10,188.00$ & & 63.72 & -562.85 & 38.74 & \\
\hline 2000 & $-1,102.97$ & 46.00 & & 24.90 & $-1,234.27$ & 60.40 & \\
\hline 2001 & -420.39 & 419.00 & & 80.77 & -941.70 & 21.54 & \\
\hline 2002 & $-1,562.15$ & $-1,008.00$ & & 25.17 & -650.63 & 71.32 & \\
\hline 2003 & -193.08 & 372.00 & & 12.40 & -573.41 & -6.47 & 2.40 \\
\hline 2004 & -489.62 & -643.00 & & 130.32 & 9.90 & 9.43 & 3.73 \\
\hline 2005 & $1,350.19$ & $1,162.85$ & & 82.00 & 55.07 & 48.68 & 1.58 \\
\hline 2006 & $1,127.20$ & $1,245.93$ & & 196.79 & -153.42 & -165.62 & 3.53 \\
\hline 2007 & $10,531.75$ & $7,139.65$ & & $3,614.02$ & -164.09 & -63.67 & 5.85 \\
\hline 2008 & $-2,828.05$ & $1,302.73$ & & $-3,259.89$ & -580.77 & -200.92 & -89.20 \\
\hline 2009 & $-11,513.75$ & $-13,434.62$ & & $3,257.85$ & -687.16 & -619.67 & -30.14 \\
\hline
\end{tabular}

Source: Airlines' annual reports as submitted to the Civil Aeronautics Board.

\section{LITERATURE REVIEW}

The deregulation of the domestic airline industry in the United States (US) in 1978 was the forerunner of similar policy shifts across the Atlantic and in other developed economies (Gillen and Morrison, 2005). Deregulation, in combination with competition, spurred growth in the airline industry (Gowrisankaran, 2002) and resulted in lower fares (Borenstein, 1992; Graham et al., 1983; Kahn, 1993; Moore, 1986), more efficient use of capital (Moore), higher productivity (Kahn, 1993), more passengers (Graham et al.), and more departures (Bailey, 1992). One of the downsides of deregulation, however, is more crowded planes (Graham et al.) and congested airports (Kahn, 1993) because of the 225\% growth in passenger traffic in the US between 1979 and 2002 (Gowrisankaran), which outpaced the growth in capacity as new entrants and weaker airlines filed for bankruptcy or were acquired by their larger rivals (Borenstein; Kahn, 1988). More crowded airplanes and congested airports tend to reduce the airlines' quality of service (Jorge-Calderon, 1997), especially in high-density markets (Kahn, 1993). While deregulation benefited most passengers, a number of incumbents and new entrants exited the industry as competition intensified and by the early 1990s, the number of airlines in the US domestic industry decreased by more than 50\% (Bailey), exacerbating cabin congestion due to the decline in the number of departures and thus capacity. The liberalization of international and regional routes has also resulted in substantial reductions in airfare (Jorge-Calderon; Maillebiau and Hansen, 1995), especially in tourist markets (Dresner and Tretheway, 1992), similar to the experience of the US domestic industry.

Fares fell as the number of competitors increased (Besanko et al., 2007; Borenstein, 1992; Maillebiau and Hansen, 1995) resulting in lower profits for most airlines. Low-cost carriers (LCCs) are the major beneficiaries of deregulation and liberalization and by offering lower fares and keeping their costs at a minimum due to fewer frills (Bailey, 1992; Shah, 2007) LCCs have flourished at a time when their larger rivals have been in and out of Chapter 11 bankruptcy protection. The competition between full service airlines and LCCs resulted in price wars as legacy airlines matched the fares offered by LCCs, driving weaker airlines into bankruptcy. The airlines resorted to price discrimination in order to increase demand and revenues and possibly profits. Price discrimination has the potential to increase the airlines' profits as a result of selling tickets at different prices and restrictions (Schwieterman, 1991) to customers with different price elasticities of demand (Pindyck and Rubinfeld, 2009). 


\section{EMPIRICAL FRAMEWORK}

The econometric model consists of two equations, profit and passenger, due to the endogeneity of the passenger variable in the profit equation. Judge et al. (1988) argue that a system of equations depicts the underlying theory of demand more realistically while Greene (1997) asserts that system methods are more efficient than singleequation methods because all available information are taken into account in parameter estimation.

The dependent variable in the profit equation is net income, which is a function of the number of passengers, an endogenous variable, and three exogenous variables - the number of passenger seats, the number of routes, and the impact of unanticipated events. Passenger traffic represents the revenue portion of the profit equation while the number of seats or capacity represents the cost portion. The profit equation is expressed as:

$$
\operatorname{PROFIT}(i j)=\beta_{0}+\beta_{1} \operatorname{PASS}(i j)+\beta_{2} \operatorname{SEAT}(i j)+\beta_{3} \operatorname{ROUTE}(i j)+\beta_{4} \operatorname{SHOCK}(i j)+\varepsilon(1, i j)
$$

where for each airline $i$ and year $j$,

PROFIT represents the net income in million PHP

PASS $\quad$ represents the total enplaned domestic passengers in thousands

SEAT represents the available domestic passenger seats in thousands

ROUTE represents the number of domestic routes with at least 1,000 passengers

SHOCK a dummy variable representing unanticipated events that affect airline profits; assumes a value of "1" from 1998-1999 for the lagged effect of the 1997 Asian financial crisis, from 2001-2002 for the impact of the 2001 terror attacks in the US, and from 2008-2009 for the impact of the most recent global financial crisis; and " 0 " otherwise

$\varepsilon$ represents the error term

Airline profits should respond positively to passenger traffic, since more paying passengers tend to increase profits, and negatively to the number of seats, since additional capacity tends to increase costs. The impact of an additional route on profits is either positive, if the additional route has adequate load factors, or negative otherwise. The impact of shocks on profits should be negative due to slower economic activity.

Passenger traffic is the dependent variable in the demand or passenger equation, which is a function of the Philippines' gross domestic product (GDP), the number of routes, and the number of inbound and outbound international passengers. The demand equation is specified as:

$$
\operatorname{PASS}(i j)=\beta_{0}+\beta_{1} G D P(i j)+\beta_{2} \operatorname{ROUTE}(i j)+\beta_{3} \operatorname{INTL}(i j)+\varepsilon(1, i j)
$$

where for each airline $i$ and year $j$,

GDP represents the real GDP of the Philippines in million PHP

INTL represents the number of inbound and outbound international passengers in thousands

The other variables are as defined in the profit equation.

Passenger traffic should respond positively to the three explanatory variables because a growing economy means more business and leisure trips, more domestic routes increase the probability of capturing the potential demand for air travel in communities that are not served or underserved by existing airlines, and more international passengers increase the number of potential passengers in the domestic airline industry since the Philippines does not allow international airlines to fly domestic routes.

\section{DATA AND METHODOLOGY}

The balanced panel data set (Baltagi, 2001; Wooldridge, 2002) comes from 56 observations representing four airlines from 1996-2009. Airline-related data such as number of passengers, load factor, departure frequency, 
and number of passenger seats; net income, revenue, and cost; and other data and information on the airline industry come from the Civil Aeronautics Board based on the documents submitted by airlines. The GDP data come from the National Statistical Coordination Board's various editions of the Philippine Statistical Yearbook.

Maillebiau and Hansen (1995) use ordinary least squares (OLS) while Dresner and Tretheway (1995), Marin (1995), and Jorge-Calderon (1997) use two-stage least squares and its weighted and indirect versions. Due to the observed heteroskedasticity and serial correlation using OLS, this paper uses the generalized method of moments (GMM) estimator based on the Newey-West covariance estimator. The instruments used in the GMM estimation are airline costs and revenues, domestic passenger traffic, capacity, number of domestic routes, international passenger traffic, and industry shocks. The GMM estimator based on the Newey-West covariance estimator has been shown to result in unbiased estimates in the presence of both heteroskedasticity and serial correlation (Greene, 1997; Johnston and DiNardo, 1997; Verbeek, 2000). Moreover, estimating the system of equations simultaneously results in unbiased and consistent estimators (Intriligator, 1996) while the fixed effects model (Johnston and DiNardo) controls for the unobserved heterogeneity between years and airlines.

\section{ESTIMATION RESULTS AND ANALYSIS}

The estimation results of the profit equation in Table 2 indicate that all explanatory variables have the expected signs. An increase of one thousand passengers results in a profit of PHP 1.989 million or PHP 1,989 per passenger. An additional capacity of one thousand seats reduces profits by PHP 1.312 million or PHP 1,312 per seat. An additional route impacts profits negatively, which may indicate that a new route will not result in enough revenues to cover its costs. This may be due to the high cost of developing and serving new routes and the lowerthan-expected passenger traffic on these routes. Moreover, the impact of an additional route on profits may be negative because most of the profitable routes have already been served and airlines that enter routes that are already served by other airlines may have difficulty breaking even. The negative and substantial impact of financial crises and terror attacks on airline profits underscores the vulnerability of the industry to unanticipated events.

Table 2: Estimation Results of the Profit Equation

\begin{tabular}{lrrr}
\hline & Coefficient & Standard error & t-Statistic \\
\hline Constant & 2246.686 & 479.814 & $4.682 * * *$ \\
PASS & 1.989 & 0.916 & $2.170 * *$ \\
SEAT & -1.312 & 0.653 & $-2.008 * *$ \\
ROUTE & -107.736 & 23.761 & $-4.534 * * *$ \\
SHOCK & -1391.103 & 495.022 & $-2.810 * * *$ \\
& & Adjusted R $\mathrm{R}^{2}$ & 0.162 \\
\hline
\end{tabular}

*** Significant at the $1 \%$ level

** Significant at the 5\% level

The estimation results of the demand equation in Table 3 indicate that the three explanatory variables impact passenger traffic positively. An increase of a billion PHP in real GDP results in 3,930 more passengers, which suggests that airlines benefit from a growing economy as business and leisure trips increase as a result of increasing economic activity and individual incomes, respectively. The coefficient of ROUTE indicates that, on average, an additional route results in 45,489 more passengers. Taking the 45,489 passengers as the annual minimum demand for a route to breakeven, all four airlines have been serving routes with fewer passengers. If airlines continue to serve routes with passenger traffic levels below the breakeven point, then airlines may be engaging in cross-subsidization in order to provide airline service in low-density markets, a more common practice in a regulated industry than in a deregulated or liberalized one (Keeler, 1972; Manuela Jr., 2007). The coefficient of INTL indicates that four out of five international passengers take domestic flights, which may be one of the reasons Philippine carriers are reluctant to open the domestic market to foreign airlines and because domestic passengers also take international flights, Philippine carriers routinely pressure the government to limit the number of departures of foreign airlines to and from gateway airports during bilateral air services agreement negotiations. 
Table 3: Estimation Results of the Demand Equation

\begin{tabular}{|c|c|c|c|}
\hline & Coefficient & Standard error & t-Statistic \\
\hline Constant & -4085.348 & 956.529 & $-4.271 * * *$ \\
\hline GDP & 3.930 & 0.849 & $4.628 * * *$ \\
\hline ROUTE & 45.489 & 17.141 & $2.654 * * *$ \\
\hline INTL & 0.805 & 0.182 & $4.431 * * *$ \\
\hline & & Adjusted $\mathrm{R}^{2}$ & 0.723 \\
\hline
\end{tabular}

*** Significant at the $1 \%$ level

\section{CONCLUSION}

This article examined the factors that affect airline profits in the Philippine scheduled passenger airline industry using data from four airlines for the period 1996-2009. The GMM estimation results indicate that an additional passenger contributes PHP 1,989 to profits while an additional seat reduces profits by PHP 1,312 , providing a compelling reason for airlines to price-discriminate and justifying the practice of heavy discounting during low season in order to stimulate demand (Besanko et al., 2007; Manuela Jr., 2007). The negative and substantial impact of developing and serving an additional route on profits may discourage airlines to serve thinlytraveled routes, which PAL abandoned in 1999 as the airline restructured its operations to stay in competition. This result may also indicate the difficulty of breaking even when an airline enters a route that is already served by another airline. The sign and magnitude of the dummy variable representing the shocks to the industry underscore the vulnerability of passenger airlines to unanticipated events such as financial crises and terror attacks.

The results and conclusion of this paper are limited to PAL, CEB, Airphil, and Zest and exclude the airlines' international operations in the analysis since only PAL and CEB have consistently operated international flights. As the other domestic airlines expand their operations to include international routes, the impact of international operations on profits, as well as the impact of foreign airlines on the international and domestic operations of Philippine carriers, should be considered in future work.

\section{AUTHOR INFORMATION}

Wilfred S. Manuela Jr. is an associate professor at the Leadership and Strategy Department, John Gokongwei School of Management, Ateneo de Manila University, Quezon City, Philippines. He received his Ph.D. in Business Administration from the University of the Philippines, Diliman in 2005. Email: wmanuela@ateneo.edu.

\section{REFERENCES}

1. Bailey, E. E. (1992). Airline deregulation: Confronting the paradoxes. Regulation: The Cato Review of Business \& Government, 15(3), 18-25.

2. Baltagi, B. H. (2001). Econometric Analysis of Panel Data, second ed. West Sussex, England: John Wiley \& Sons.

3. Besanko, D., Dranove, D., Shanley, M., and Shaefer, S. (2007). Economics of Strategy, fourth ed. New York: John Wiley \& Sons.

4. Borenstein, S. (1992). The evolution of US airline competition. Journal of Economic Perspectives, 6(3), 45-73.

5. Civil Aeronautics Board, Pasay City, Philippines. Airline-related data and information from 1995-2009.

6. Dresner, M. and Tretheway, M. W. (1992). Modeling and testing the effect of market structure on price: The case of international air transport. Journal of Transport Economics and Policy, 26(2), 171-184.

7. Gillen, D. and Morrison, W. G. (2005). Regulation, competition and network evolution in aviation. Journal of Air Transport Management, 11(3), 161-174.

8. Gowrisankaran, G. (2002). Competition and regulation in the airline industry. FRBSF Economic Letter 2002-01.

9. Graham D. R., Kaplan, D. P., and Sibley, D. S. (1983). Efficiency and competition in the airline industry. Bell Journal of Economics and Management Science, 14, 118-138.

10. Greene, W. H. (1997). Econometric Analysis, third ed. Upper Saddle River, NJ: Prentice-Hall. 
11. Intriligator, M. D. (1996). Econometric Models, Techniques, and Applications, second ed. Upper Saddle River, NJ: Prentice-Hall.

12. Johnston, J. and DiNardo, J. (1997). Econometric Methods, fourth ed. New York: McGraw-Hill.

13. Jorge-Calderon, J. D. (1997). A demand model for scheduled airline services on international European routes. Journal of Air Transport Management, 3(1), 23-35.

14. Judge, G. J., Hill, R. C., Griffiths, W. E., Luetkepohl, H., and Lee, T-C. (1988). Introduction to the Theories and Practice of Econometrics, second ed. New York: John Wiley \& Sons.

15. Kahn, A. E. (1988). Surprises of airline deregulation. American Economic Review, 78(2), $316-322$.

16. Kahn, A. E., (1993). Airline deregulation. The Concise Encyclopedia of Economics. Available at http://www.econlib.org/library/Enc1/AirlineDeregulation.html; accessed March 10, 2011.

17. Keeler, T. E. (1972). Airline regulation and market performance. Bell Journal of Economics and Management Science, 3, 399-424.

18. Maillebiau, E. and Hansen, M. (1995). Demand and consumer welfare impacts of international airline liberalization: The case of the North Atlantic. Journal of Transport Economics and Policy, 29(2), 115-136.

19. Manuela Jr., W. S. (2007). Airline liberalization effects on fare: The case of the Philippines. Journal of Business Research, 60(2), 161-167.

20. Moore, T. G. (1986). U.S. airline deregulation: Its effects on passengers, capital, and labor. Journal of Law and Economics, 29(1), 1-28.

21. National Statistical Coordination Board (2010 and earlier editions). Philippine Statistical Yearbook, Makati City, Philippines.

22. Pindyck, R. S. and Rubinfeld, D. L. (2009). Microeconomics, seventh ed. Upper Saddle River, NJ: Prentice-Hall.

23. Schwieterman, J. P. (1991). Fare is fair in airline deregulation: Restrictions and the pursuit of allocative efficiency. Regulation: The Cato Review of Business \& Government, Currents, 14(3), 29-34.

24. Shah, A. J. (2007). Southwest Airlines Co. - 2007. In David, F. R., Strategic Management: Concepts and Cases, thirteenth ed. Singapore: Pearson, 199-210.

25. Thompson Jr., A. A. and Gamble, J. E. (2001). Southwest Airlines, Inc. In Thompson Jr., A. A. and Strickland III, A. J., Strategic Management: Concepts and Cases, thirteenth ed. New York: McGraw-Hill, C590-C629.

26. Verbeek, M. (2000). A Guide to Modern Econometrics. West Sussex, England: John Wiley \& Sons.

27. Wooldridge, J. M. (2002). Econometric Analysis of Cross Section and Panel Data. Cambridge, MA: MIT Press. 